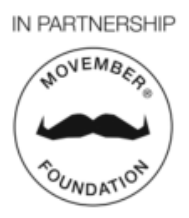

\title{
Designing \& implementing a primary care-led pathway for stable prostate cancer patients
}

\section{Introduction}

The Transforming Cancer Services Team (TCST) supports the delivery of NHS England's Five Year Forward View and National Cancer Strategy across London. Working with commissioners, providers, alliances, charity partners and other stakeholders to support delivery of cancer waiting targets, earlier diagnosis of cancer, those who are living with and beyond cancer (LWBC) and to increase the pace of improvement. We provide strategic leadership for cancer across London as well as supporting our stakeholders.

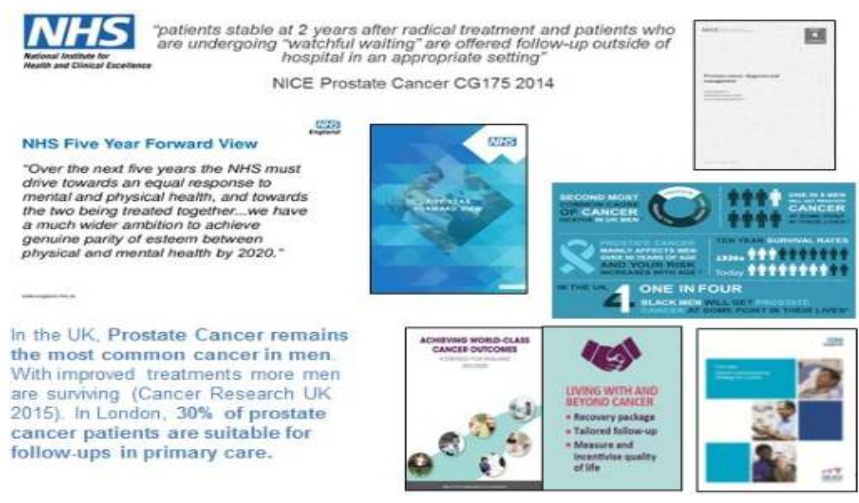

\section{Numbers for of patients transferred during 2015 pilot site}

\begin{tabular}{|l|l|l|}
\hline $\begin{array}{l}\text { Number of new patients identified at Croydon } \\
\text { University Hospital and Royal Marsden NHS }\end{array}$ & Start of project & End of project \\
\hline $\begin{array}{l}\text { Trust } \\
\begin{array}{l}\text { Welcome Appointments attended (new } \\
\text { patients transferred as part of intervention) }\end{array}\end{array}$ & $\mathrm{n} / \mathrm{a}$ & $\mathrm{n} / \mathrm{a}$ \\
\hline $\begin{array}{l}\text { Patients lost to follow-up pre-intervention } \\
\text { Patients lost to follow-up recalled }\end{array}$ & 57 & 86 \\
\hline $\begin{array}{l}\text { Total number of patients having } \\
\text { primary care follow-up }\end{array}$ & 450 & $\mathrm{n} / \mathrm{a}$ \\
\hline
\end{tabular}

\section{Results}

\section{Projected number of patients for London}

\begin{tabular}{|c|c|c|c|c|c|}
\hline London STP & $\begin{array}{c}\text { Total } \\
\text { prevalence } \\
\text { prostate (22 } \\
\text { year } \\
\text { prevalence } \\
2013)\end{array}$ & $\begin{array}{l}\text { New cases } \\
\text { per year* }\end{array}$ & $\begin{array}{l}\text { Estimated 1- } \\
\text { yr Survival } \\
\text { Cases }^{\star *}\end{array}$ & $\begin{array}{c}\text { Estimated } \\
\text { watchful wait } \\
\text { patients }{ }^{* * *} \\
\text { (backlog of } \\
\text { prevalent } \\
\text { cases) }\end{array}$ & $\begin{array}{c}\text { Estimated } \\
\text { cohort per } \\
\text { year } r^{t * \star} \text { (watchful } \\
\text { waits) }\end{array}$ \\
\hline North Central & 5322 & 679 & 658 & 1597 & 197 \\
\hline North East & 7427 & 859 & 820 & 2228 & 246 \\
\hline South East & 6772 & 1104 & 1060 & 2032 & 318 \\
\hline South West & 6449 & 979 & 942 & 1935 & 283 \\
\hline North West & 6952 & 993 & 957 & 2086 & 287 \\
\hline $\begin{array}{l}\text { London } \\
\text { (excluding } \\
\text { West Essex) }\end{array}$ & 32922 & 4614 & 4437 & 9878 & 1331 \\
\hline
\end{tabular}

-Source: Public Health England (NCN). Prevdenoe Crude rate of registered canoer pabents alive at 31/12/2013

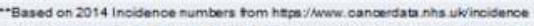
Based on incidence -1 -Yr Sunvival \% by $C C O$. If CCS surwival number was not avalable, the London average wa ....Caloulated based on the assumed $30 \%$ of prostate patients who are watchtou waiters

527 patients safely transferred to primary care of 61 practices and a further 420 practices across 20 CCGs have signed up to provide the service for their patients. All 5 London STPs have plans to roll out the pathway by which will release over 11,000 hospital appointments per year.

\section{Objectives and Methodology}

As NICE (2014) recommends "patients stable two years after radical treatment or undergoing watchful waiting are offered follow-up outside hospital" \& the Strategy calls for "care close to home", we developed in collaboration with patients, commissioners and clinicians, a holistic primary care pathway for stable prostate cancer patients that

- Safely transfers patients to primary care with clear safety netting processes

- Improves patient experience, improves information about their follow-up care and enhances self-management

- Provides training for primary care professionals to address and manage patient's medical and holistic needs

- Is governed by a service specification

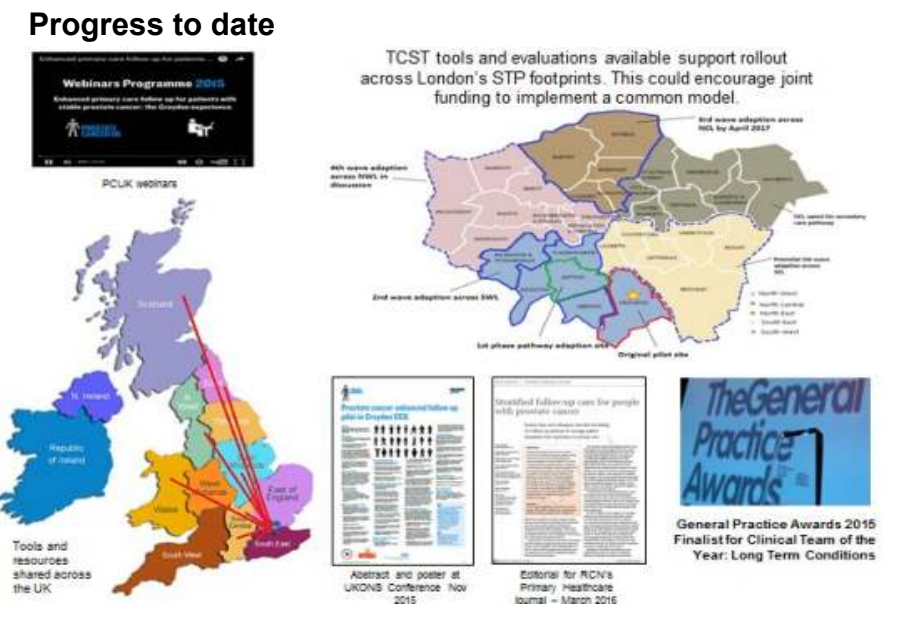

\section{Conclusions}

The pathway demonstrates the feasibility of a primary care-led follow-up service that's cost effective, holistic, supports self-management and integrates prostate cancer follow-up into long term condition management. Reducing the variation in service provision remains a challenge.

Patients and clinicians are in favour of primary care follow-up. Communicating change in care is important and would be appropriate for secondary care clinician to advice patient of the transfer.

Clinical safety was achieved through the maintenance of the prostate register. Safer and clinically more robust than previous primary care-led models. 